\title{
The Impact of Globalisation on South African Businesses: Some Leadership Thoughts
}

\author{
Gillian McMahon \\ Department of Human Resource Management, University of Pretoria, South Africa, 2000 \\ Nicolene Barkhuizen \\ Department of Industrial Psychology, North-West University, Mmabatho, South Africa, 2745 \\ nicolene.barkhuizen@nwu.ac.za \\ Nico Schutte \\ Department of Public Administration, North-West University, Mmabatho, South Africa, 2745
}

\section{Doi:10.5901/mjss.2014.v5n9p215}

\section{Abstract}

The main objective of this research was to explore the impact of globalisation on South African businesses from the perspective of business leaders. A qualitative research approach was followed with semi-structured interviews conducted with five business leaders. The findings showed that the global economic crises, legislation, sustainability, stakeholder engagement, poverty and increased competitiveness are the key factors relating to globalisation and the impact thereof on South African businesses. The outcomes of this study can assist current business leaders in taking cognisance of global factors affecting their business and take proactive measures to eliminate the adverse impact of a rapid changing business environment.

Keywords: Globalisation, Leadership, Business Challenges, Technology, Stakeholder engagement

\section{Introduction}

The globalisation of the South African economy brings about new challenges in the way in which leaders have to operate their business. The global economy has become, and will continue to become more integrated, presenting a business environment characterised by a global interdependence of resources, suppliers, product markets and business competition (Khoza, 2009; Shokane, Stanz \& Slabbert, 2004; Yin, Lee \& Wang, 2014). Like other emerging countries entering the global arena South Africa is required to shift from its current internally focused economic practices to openmarket practices (Magner, 2008; Shokane et al., 2004) and include the broader environmental aspects of society (Chipunza \& Gwarinda, 2010; Geldenhuys \& Veldsman, 2011; Mokgolo, Mokgolo \& Modiba, 2012). Consequently, if South Africa is to successfully make its mark as an upcoming nation it must increase its competitiveness, diversify its economy, gain access to capital, grow small businesses and work together to participate in the global negotiations that shape the world trading system (Cetron \& Davies, 2008).

This requires major paradigm shifts in the leadership of South African organisations. South African leaders, more than ever have to draw on suitable leadership competencies to successfully grow these businesses in an environment that requires development, a social contribution and innovation (Alsaeedi \& Male, 2013; Stock \& özbek-Potthoff, 2014; Story, Barbuto, Luthans \& Bovaird, 2014). This triggers the need to understand, more specifically, the global challenges facing businesses and business leaders in South Africa as well as the implications of these challenges on future leadership requirements (Hernez-Broome, 2004; Magner, 2008). In addition it also raises various questions around leadership requirements in an economy that is slowly emerging from the recent economic crisis and a country that is still in its emergent stages of development. Many researchers are in agreement that that $21^{\text {st }}$ century leaders still need to acquire the necessary skills and competencies to manage in the new global business arena (Ahnlid \& Elgström, 2014; Cseh, Davis \& Khilji, 2013; Sharabi, 2014; Terell \& Rosenbusch, 2013). In fact some researchers label organisational leaders as a disease because of their simplistic, centralised and hierarchical approaches toward managing organisations (Pearce and Manz, 2014).

Against this background the main objective of this research was to explore the impact of globalisation on South African businesses from the perspective of business leaders. Despite a proliferation of research on leadership in the 
South African context, very limited research currently exists on South African leadership in a global arena. Most researchers and experts alike are in consensus that changes in the business environment over the last decade have significantly transformed the way businesses in which businesses are run. Identifiable influences include technology, labour, management, knowledge, poverty and inequality (Latham, 2013). Advances in technology have changed all dimensions of business in the past decade, altering the way we behave in our work and social environment (Gaur, 2006). These technological changes incorporate advances in science, the internet and transport, but to mention a few (Khoza, 2009). Such advancements generally lead to increased outsourcing whilst at the same time result in certain job losses, poverty and unemployment. Moreover, new technologies require a higher level of training and advanced skills which in effect present many challenges to businesses operating in emerging markets such as South Africa, the latter typically characterised by poor education and low skills levels (Cetron \& Davies, 2008).

In addition the shift to an information-based organisation from the old style command-and-control model has resulted in flatter management structures and fewer managers than before (Cetron \& Davies, 2008). The dismantling of traditional hierarchies and the emergence of network organisations has shifted the focus from managing resources to managing multiple stakeholder relationships (Sharabi, 2014; Mbugua \& Rarieya, 2014). As mentioned by Maak (2007) good stakeholder relationships are crucial to organisational sustainability and business success. Leaders should therefore become more responsible to enable sustainable and mutual beneficial relationships with stakeholders to attract stakeholder trust and investment (Maak, 2007; Mahembe \& Engelbrecht, 2014; Van Aswegen \& Engelbrecht, 2009; Wolf, 2014).

Finally labour markets will also remain tight, particularly in skilled fields, as developing countries continue to strive for better educational systems whilst developed countries confront the reality of an ageing workforce (Colley \& Price, 2008; Tishman, van Looy \& Bruyere, 2012). Research clearly points out that a shift towards specialisation, an increase in education and training, a changing work ethic, a later retirement age and a distinct generation gap is evident (Breevaart et al., 2014; Rhein, 2013). Organisations will be forced to re-evaluate their approach to employees as the new generation will quickly move on if they do not feel fulfilled. Training and development will thus play a crucial role in the retention of such employees (Cetron \& Davies, 2008; Mclaggan, Bezuidenhout \& Botha, 2013; Nzukuma \& Bussin, 2011).

The next section of the article discusses the research method employed for this study. Flowing from the method, the empirical results of the research are reported. The research concludes with a discussion of the key results and recommendations for both practice and future research.

\section{Research Design}

\subsection{Research Approach}

A qualitative case study research approach was followed in this study. Qualitative research was deemed the most appropriate method for this research as the aim was to explore leaders' perceptions of the impact of globalisation on South African organisations. Qualitative research is concerned with explanation building that requires the understanding of complexity, detail and sensitivity of the social context in which it is produced (Leedy \& Omrod, 2005). Case study research investigates a contemporary phenomenon within its real-life context; when the boundaries between phenomenon and context are not clearly evident and in which multiple sources of evidence are used (Yin, 2009). The data was collected through semi-structured interviews. The study was approached by the relevant authorities and ethics committees. The study adhered to all ethical principles of scientific research.

\subsection{Sampling}

The target population comprised corporate leaders in the private business sector of South Africa. The participants were selected on a purposive convenience based on the following criteria:

- a good understanding of the micro- and macro-environments in which their businesses operated;

- a fair understanding of the current economic and social challenges faced by South Africa as a country as well as businesses operating in South Africa;

- at least five years experience in a strategic leadership role to have an understanding of leadership competencies.

Most of the participants were Male, White and in possession of a degree. All of the participants were employed on Executive Management level and had a minimum of 15 years of leadership experience. A brief background description of each participant is presented in Table 1 below. 
Table 1: Demographic Characteristics of Participants

\begin{tabular}{|c|c|}
\hline Participant & ackground \\
\hline P1 & $\begin{array}{l}\text { Participant } 1 \text { is a black female executive who has been working for a large, multinational audit company for the past } 22 \text { years. She } \\
\text { had progressively advanced in the ranks to become the first black female partner and subsequently the Chair of this same company. } \\
\text { She is a chartered accountant and holds several degrees in accounting, business and economics. This participant has a wealth of } \\
\text { experience in various leadership roles and has worked with people at all levels during her career. The participants could relate, } \\
\text { firsthand, to the challenges experienced in business and particularly the discrimination she initially experienced as a black female in a } \\
\text { corporate company in South Africa. }\end{array}$ \\
\hline P2 & $\begin{array}{l}\text { Participant } 2 \text { is a White male who is a qualified chartered accountant and experienced business leader. This participant spent his } \\
\text { career in several companies as financial manager, financial director and then as managing director. Currently he is the Chief } \\
\text { Executive Officer of a group of companies that make up a division of a large JSE listed group. He holds a wealth of experience in both } \\
\text { a specialist role and has various leadership roles. His businesses have been highly profitable and have flourished over the past years. } \\
\text { He maintains that this can be attributed to successful leadership. This participant in particular stressed the need for leaders to have } \\
\text { strong financial background and highly developed entrepreneurial skills. }\end{array}$ \\
\hline P3 & $\begin{array}{l}\text { Participant } 3 \text { is a coloured male who holds a business degree and has many years of experience in business, both as an } \\
\text { entrepreneur and a corporate leader. This individual began his career as a driver and has subsequently progressed in the business to } \\
\text { become a well-known entrepreneur, investor and corporate leader. I felt extremely privileged to work with him during this study as he } \\
\text { was able to contribute a great deal in terms of his personal experiences and challenges experienced over the years in corporate } \\
\text { leadership. This participant stressed the importance of a strong financial background and good communication skills as being integral } \\
\text { to successful leadership. He also pointed out the importance of leading in the context of South Africa and is of the view that corporate } \\
\text { leaders in South Africa should take on an Afrocentric approach. }\end{array}$ \\
\hline P4 & $\begin{array}{l}\text { Participant } 4 \text { is a white male who has a wealth of experience in corporate leadership. He spent many years of his career as the } \\
\text { Marketing Director and then Managing Director of a large, international motor manufacturing company. He subsequently joined his } \\
\text { current organisation as Chief Executive Officer of a large motor retail and financial services group in South Africa. He was able to } \\
\text { share valuable personal experiences in business and particularly in the area of corporate leadership. This participant is well-versed in } \\
\text { leadership and often presents papers on the subject of leadership at business schools, corporate conferences and functions. I felt that } \\
\text { this participant in general had a well-rounded perspective on leadership globally, and particularly, as applicable to South Africa. This } \\
\text { participant reflected on the importance of servant leadership in the South African context and the need for strong, principled } \\
\text { leadership into the future. }\end{array}$ \\
\hline P5 & $\begin{array}{l}\text { Participant } 5 \text { is a white female and currently the Managing Director of a large corporate travel management business. She spent her } \\
\text { entire career in this business, advancing from a specialist travel consultant through the ranks to her current position. She was able to } \\
\text { share her experiences and challenges relating to leadership and also provided valuable insights on her perspectives regarding } \\
\text { general challenges facing businesses and the need for credible leadership. She stressed the importance of integrity as the base } \\
\text { requirement for any corporate leader. }\end{array}$ \\
\hline
\end{tabular}

\subsection{Data Analyses}

Content analyses were used to analyse the data. Content analyses are frequently applied in qualitative studies with the aim of obtaining a condensed and broad description of the phenomenon and well as the concepts and categories describing a phenomenon (Elo \& Kyngas (2008). Analysis began with a process of tidying up the information collected, whereby the data collected was categorised. Next, the researcher analysed the data to identify themes and sub-themes. This process was a good method of creating an initial framework to attach an analysis of the research outcomes. Content analyses thus can show how data can be analysed in a systematic way and scientific rigour manner (Thyme, Wiberg, Lundberg \& Graneham, 2013).

\section{Findings}

The analyses of the data resulted in six main themes:

- Global Economic Crises

- Legislation

- Sustainability

- Stakeholder Engagement

- Poverty and unemployment

- Increased competitiveness

These themes are briefly discussed in the ensuring section.

\subsection{Theme 1: Global Economic Crises}

What emerged as the most significant challenge facing businesses globally was the impact of the recent global economic crisis. Participants felt that the cause was greed on the part of corporate leaders, and the mismanagement of funds by 
these individuals. The main consequence of this crisis was seen in the tighter controls that were put in place regarding accessibility to credit. In turn, this had a negative effect on businesses, even those with excellent credit ratings, in that it restricted their ability to expand or invest. Participants shared their knowledge of businesses worldwide, and locally, that were battling to survive as a result of the credit squeeze. The end result was that fewer international companies were investing in local businesses and local businesses were hesitant to expand their operations. Some of the comments by the participants included:

"Probably, we've just debated now, this entire credit squeeze and the risk of not being able to borrow money properly and that's happening even to Company $X$ which is a good company. Access to reasonably priced funding has a dramatic effect on your ability to trade." (Participant 2) and

"Well, the global debt crisis has affected all the leading nations and all the emerging nations in different forms and that has resulted in less investment in businesses and in infrastructure and development." (Participant 3)

\subsection{Theme 2: Legislation}

The introduction of new legislation was viewed negatively and participants expressed high levels of frustration around this. The view was that these laws posed more of a hindrance to business rather than assisting businesses to grow. Participants felt that companies were spending far too much time, money and resources on compliance issues. This had directed the focus in business to compliance as opposed to productivity and growth, misdirection in their view. Legislation and associated compliance measurements mentioned were the National Credit Act of 2003, Corporate Governance for South Africa, The Consumer Protection Act of 2008 and the Broad-Based Black Economic Empowerment Act, 2003. Some of the comments by the respondents included:

"Honestly I think that because of all the drama we've had worldwide, this new corporate governance is just destroying your ability to trade. The guys are actually getting a bit concerned as they are not trading in their normal course in case they step out of line. It's an impediment." (Participant 2) and

"So now there's this massive swing to the other side of where nobody is trusted. So from trusting people 100 per cent and whole-heartedly with responsibilities way beyond what they should ever have been allowed to deal with you now have this incredible focus on corporate governance. You've got to cover your tracks and make sure that everything is done correctly and the sad thing about that is that there is so much cost to the business about putting all of those structures in place. It takes away from what one wants to see in entrepreneurship." (Participant 3)

\subsection{Theme 3: Sustainability}

Sustainability was identified as a key trend and challenge to businesses. Although participants acknowledged the importance of sustainability, they also voiced the same levels of frustration regarding the requirements. These issues were pretty much the same as those raised under legislation. It requires that businesses shift gears from being purely bottom line driven to adopting a more integrated approach. This entails a more holistic evaluation of how businesses interact, impact and contribute to the social, political and economic pillars of sustainable development. Participants also viewed sustainability as another form of compliance. One participant fully supported the objective, however, admitted that businesses were generally not taking it seriously on the basis that it was not seen as part of the local business culture. Some of the comments by the participants included:

"I think one of the challenges facing businesses globally is the definition of the role of business in society and I think this question has been a long time coming, but recent events have made this issue more obvious. Now you must suddenly worry about how is our product going to impact the community but that kind of debate is not in the boardroom to the extent that it should be, even given the whole conversation about the environment." (Participant 1) and

"...sustaining the world's resources is a major challenge." (Participant 3) and

"We've got sustainability becoming a major issue and all of those are around putting more frameworks, if you like, around businesses." (Participant 5)

\subsection{Theme 4: Stakeholder Engagement}

Stakeholder engagement was raised in conjunction with the issue of sustainability. Participants raised this in the context of increased pressures on reporting. They felt that businesses were being placed under more pressure to report on things 
that they never had to report on before. Corporate stakeholders, in the form of employees, customers, shareholders and suppliers, were becoming more interested in what businesses were doing and how they were doing it. More and more questions are being asked of businesses and the general feel was that you constantly have to "cover your back". Some of the comments of the participants included:

"Corporates, more than ever before, find themselves having to deal with individuals or stakeholders that they've never had to worry about before and this is really creating huge problems for them. If you had to ask me... a lot of leaders are still sticking their head in the sand, they're pretending that the noises are not real... that's my view." (Participant 1)

\subsection{Theme 5: Poverty and Unemployment}

Poverty and the associated consequences of unemployment were raised as serious concerns. Participants viewed poverty as a major challenge to businesses across the globe. The recent debt crisis had been a major contributor to higher unemployment rates. The lack of investment by businesses had also limited employment opportunities and further investment in skills. Some of the comments of the participants included:

"Well, combating poverty would be high on the list. Combating poverty whilst at the same time sustaining the world's and resources." (Participant 3)

"The global debt crisis has affected all the leading nations and all the emerging nations in different forms and that has resulted in less investment in businesses and infrastructural development. That that has really affected the world because countries have not been able to create employment." (Participant 4) and

"At the same time, through the diminished tax receipts coming from less profitable businesses have provided governments with less money to provide education, skills and infrastructure development." (Participant 5)

\subsection{Theme 6: Increased Competiveness}

The complexity of the environment and recent changes in the business environment presented further challenges to organisations. The biggest change was described as increasing competition and a new world market. Also mentioned was the changing customer profile, the shortage of top talent and the rapidly advancing phases of technology. The challenge for corporates and business leaders was to acknowledge the changes and then adapt their strategies in order to be successful in this new environment. As mentioned by one of the respondents:

"We're living in a volatile and ever-changing world and in an extremely competitive world and obviously linked to that there's an enormous war for talent going on...and "From a global point of view, the whole balance of power is changing so the traditional paradigms do not exist anymore. If you look at the vehicle market, the new vehicle market in China became the number one new vehicle market in the world. In the past, in the US, they used to sell 17 million vehicles per annum. Last year, they only sold 10.6 million whilst China sold 1.5 million vehicles. And you just look at the emergence of countries like China. In India they sell more than 3 million vehicles a year... Russia, Brazil..." (Participant 4)

\section{Discussion}

The main objective of this research was to explore the perceived impact of globalisation on business leaders in South Africa. The findings showed that most of global challenges raised by the participants include the increasing demands of the global economic crises, legislative requirements, stakeholder relationships and, to a lesser extent, the issues of poverty, unemployment, increased competition, skills, technology and talent. Specific findings included the increase in technology and the associated consequences of job losses; the increasing need for more specialised levels of training; more advanced skills requirements; the shrinking skills pool in developing countries and the ageing workforce in developed countries; the widening generation gap that will force businesses to review their approach to employees; a changing work ethic; poor education systems, the need for greater efficiencies and higher levels of creativity; flatter organisation structures; the shift from traditional hierarchies to network organisations and the change in the sources of competitive advantage.These findings are in line with previous research that highlights the potential global factors that impact South African businesses and their leaders (see Cetron \& Davies, 2008; Khoza, 2009; Latham, 2013; Sharabi, 2014; Mbugua \& Rarieya, 2014).

This research had some limitations. The qualitative approach limited the research in terms of generalising the findings to other population groups. Future research can benefit by including a larger sample to make comparison of results possible between different generations of leaders. Finally a longitudinal research approach can be adopted to 
track leadership challenges over longer periods of time and present solutions for leaders to deal effectively with an ever changing business environment.

In conclusion this research contributed to the limited body of knowledge that currently exists on the impact of globalisation on South African organisations and their leaders. The findings of the research also lend itself to practical interventions that business leaders can use to improve key stakeholder relationships and the identification of talented employees and skills training to remain competitive and sustainable. Finally this research also creates an awareness of the increased complexity of the global business environment and the need for leaders to increase their own competence to manage effectively in the $21^{\text {st }}$ century workplace.

\section{References}

Alsaeedi, F., \& Male, T. (2014). Transformational Leadership and Globalisation: Attitudes of School Principals in Kuwait. Educational Management Administration \& Leadership, 41(5), 640-657.

Ahnlid, A., \& Elgström, O. (2014) Challenging the European Union: The rising powers and the USA in the Doha Round. Contemporary Politics, 20(1), 77-89.

Breevaart, K., Bakker, A., Hetland, J., Demerouti, E., Olsen, O.K. et al. (2014). Daily transactional and transformational leadership and daily employee engagement. Journal of Occupational and Organisational Psychology, 87, 138-157.

Cetron, M.J. \& Davies, O. (2008). Trends shaping tomorrow's world. Bethesda, MD, USA, World Future Society

Chipunza, C., \& Gwarinda, S.A. (2010). Transformational leadership in merging higher education institutions: A case study. SA Journal of Human Resource Management/ SA Tydskrif vir Menslikehulpbronbestuur, 8(1), 1-10.

Colley, L \& Price, Robin A. (2008) Planning for an Aging Workforce. In Brown, Kerry A. and Mandell, Myrna and Furneaux, Craig W. and Beach, Sandra, Eds. Proceedings Contemporary Issues in Public Management: The Twelfth Annual Conference of the International Research Society for Public Management (IRSPM XII), pages pp. 1-15, Brisbane, Australia.

Cseh, M., Davis, E.B., \& Khilji, S. E. (2013). Developing a global mindset: learning of global leaders. European Journal of Training and Development, 37(5), 489-499.

Gaur, A.S. 2006. Changing demands of leadership in the new economy: a survey of Indian leaders. IIMB Management Review, 18(2):149-158.

Geldenhuys, C.A., \& Veldsman, T.H. (2011). A change navigation-based, scenario planning process within a developing world context from an Afro-centric leadership perspective. SA Journal of Human Resource Management, 9(1), 1-17.

Hernez-Broome, G. (2004). Leadership development: past, present, and future. Human Resource Planning, 27(1), 24-32.

Khoza, R. (2009). The future of business leadership: challenges for the $21^{\text {st }}$ century. Management Today, 25(1):10-13.

Latham, S. (2014). Leadership Research: An Arts-informed perspective. Journal of Management Inquiry, 23(2), 123-132.

Leedy, P. \& Ormrod, J.E. (2005). Practical research: planning and design (8 $8^{\text {th }}$ ed.). New Jersey: Prentice Hall

Maak, T. (2007). Responsible Leadership, Stakeholder Engagement, and the Emergence of Social Capital. Journal of Business Ethics, 74, 329-343.

Magner, C. 2008. Contextual leadership development: a South African perspective. European Business Review, 20(2), 128-141.

Mahembe, B., \& Engelbrecht, A.S. (2014). The relationship between servant leadership, organisational citizenship behaviour and team effectiveness. SA Journal of Industrial Psychology, 40(1), 1-10.

Mbugua, F., \& Rarierya, J.F.A. (2014). Collaborating strategy: myth or reality? Educational Management Administration \& Leadership, 42(1), 99-111.

Mclaggan, E., Bezuidenhout, A., \& Botha, C.T. (2013). Leadership style and organisational commitment in the mining industry in Mpumalanga. SA Journal of Human Resource Management/SA Tydksrif vir Menslikehulpbronbestuur, 11(1), 1-9.

Mokgolo, M.M., Mokgolo, P., \& Modiba, M. (2012). Transformational leadership in the South African public service after the April 2009 national elections. SA Journal of Human Resource Management/SA Tydskrif vir Menslikehulpbronbestuur, 10(1), 1-9.

Nzukuma, K.C.C., \& Bussin, M. (2011). Job-hopping amongst African Black senior management in South Africa. SA Journal of Human Resource Management, 9(1), 1-12

Pearce, C.L., \& Manz, C.C. (2014). The leadership disease...and its potential cures. Business Horizons, 74, 215-224.

Rhein, D. (2013). The workplace challenge: Cross-cultural leadership in Thailand. ISEA, 41(1), 41-55.

Sharabi, M. (2014). Today's quality is tomorrow's reputation (and the following day's business success). Total Quality Management \& Business Excellence, 25(3-4), 183-197.

Shokane, M.S., Stanz, K.J. \& Slabbert, J.A. (2004). Description of leadership in South Africa: organisational context perspective. SA Journal of Human Resource Management, 2(3), 1-6.

Stock, R.M. \& Özbek-Potthoff, G. (2014). Implicit leadership in an intercultural context: theory extension and empirical investigation. The International Journal of Human Resource Management, 25(12), 1651-1668.

Story, J.S.P., Barbuto, J.E. Jr, Luthans, F., \& Bovaird, J.A. (2014). Meeting the challenges of effective international HRM: Analyses of the antecedents of global mindset. Human Resource Management, 53(1), 131-155.

Terrell, R.S., \& Rosenbusch, K. (2013). How global leaders develop. Journal of Management Development, 32(10), 1056-1079.

Thyme, K. E., Wiberg, B., Lundman, B., \& Graneheim, U.H. (2013). Qualitative content analysis in art psychotherapy research: Concepts, procedures, and measures to reveal the latent meaning in pictures and the words attached to the pictures. The Arts in Psychotherapy, 40, 101-107.

Tishman, F.M., Van Rooy, S., \& Bruyère, S.M. (2012). Employer strategies for responding to an ageing workforce. NTAR Leadership Centre, New Brunswick, NJ.

Wolf, J. (2014). The Relationship between Sustainable Supply Chain Management, Stakeholder Pressure and Corporate Sustainability Performance. Journal of Business Ethics, 119, 317-328.

Yin, R.K. (2009). Case Study Research Design and Methods (4th ed.). Sage Publications, Thousand Oaks

Yin, H., Lee, J.C., \& Wang, W. (2014). Dilemmas of leading national curriculum reform in a global era: A Chinese perspective. Educational Management Administration \& Leadership, 42(2), 293-311. 